\title{
Dynamics of Health Expenditures in OECD Countries: Panel ARDL Approach
}

\author{
İbrahim Doğan', Nadide Sevil Tülüce ${ }^{2}$, Aydan Doğan ${ }^{3}$ \\ ${ }^{1}$ Department of Economics, FEAS, Bozok University, Yozgat, Turkey \\ ${ }^{2}$ Department of International Trade and Business, FEAS, Kayseri, Turkey \\ ${ }^{3}$ Department of Health, Bozok University, Yozgat, Turkey \\ Email: ibrahimabdogan@gmail.com, nadidehalici@gmail.com
}

Received 30 June 2014; revised 28 July 2014; accepted 26 August 2014

Copyright (C) 2014 by authors and Scientific Research Publishing Inc.

This work is licensed under the Creative Commons Attribution International License (CC BY). http://creativecommons.org/licenses/by/4.0/

\section{c) (7) Open Access}

\begin{abstract}
This study used a panel data set, which is including 15 OECD countries that had high income per capita for the time period of 1995-2011. Following causality and autoregressive distributed lag (ARDL), paper yields: 1) respectively the largest and the smallest impacts on health expenditures are caused by public spending and the influences of Age Dependency Ratio Young (ADRY); 2) income and Age Dependency Ratio Old (ADRO) on health expenditures are positive; 3) another striking inference is that while young working population rate is increasing, health expenditure is decreasing.
\end{abstract}

\section{Keywords}

\section{Health Expenditure, Panel ARDL, Economic Growth}

\section{Introduction}

The development of modern economic growth literature begins with the research title, "A Contribution to the theory of economic growth" of Solow [1]. This theory, as a known Neo-classical growth theory, gives place to endogenous growth models in the second half of the 1980s. Endogenous growth models have been focused on increasing returns along with human capital factors and technological developments. Modern Growth Theory exhibits that the economic growth resulted from the increasing returns is associated with new knowledge. Therefore, the components of the endogenous growth models, which are also known as modern production factors are: physical capital, human capital, skilled and unskilled labor, natural resources, technology and entrepreneurs.

Neoclassical growth theories suggest that the long-run rate of growth is determined by the rate of change of 
intangible technology. Furthermore, this change in technology is independent from the savings and the investment rate of the economy. Human capital is commonly thought to be the knowledge and the skills that are embodied in the labor force. The general well-being of the labor force, concerning health and nutrition, is also sometimes considered as a part of the human capital. Human capital accumulation depends on the fraction of total savings per worker that is allocated to education, job training and health, etc. [2]

Schultz [3] demonstrated that many studies related to education, nutrition, health, labor mobility and training have sought to measure the contribution of these forms of human capital to the productivity of workers and to modern economic growth. By Lucas [4], person's productivity of human capital is described as focusing on the division of activities over time. There are two types of capital, according to the study. Firstly, under the neoclassical approach, similar technology is used in the production and accumulation of capital. Secondly, human capital is increasing the productivity of both labor and capital. In parallel to this definition, Barro [5] has stated that human capital accumulation is an important part of the development process, and this accumulation is significantly affected by public programs, like education and health. According to the studies of Romer [6], Lucas [4] and Barro [5], as the pioneers of endogenous growth models, human capital is an important component of economic growth. The most important components of human capital are education and health care. Thus, the relationship between health expenditure and physical capital accumulations has an important role in long-run economic growth. In this paper, we empirically focus on the impact of health, as an investment in human capital, on economic growth in OECD panel countries. The study contributes to the existing literature on health and growth in two aspects: at first, we examine the direction of the relationship between economic growth and health expenditure and then the long-term effects on this relationship.

The rest of this article will be monitored as follows: Section 2 discusses the relationship between human capital, health expenditure and economic growth. Then the estimation results of the econometric analysis will be included in Section 3. Finally in Section 4, conclusions take place.

\section{Human Capital, Health Expenditure and Economic Growth}

In recent decades, health expenditure in the OECD countries differs considerably over time and across countries. In the other words, the ratio of health spending to GDP has been increased in OECD countries. For example, in USA health expenditures-GDP ratio is 13.59 until 1995, and it became 17.85 in 2011, according to the statistics of WHO (World Health Organization). In the same period, these rates are increased for developed countries (For example Netherlands (8.32 - 11.95).

The policy implication of the effect of human capital investment and health expenditure on economic growth has been an important subject of academic research, in recent decades. Since the studies of Kleiman (1974) and Newhouse (1977), income has been identified as the most important factor, explaining differences across countries in the level and growth of health care expenditure [7].

Various studies have explored the performance of health expenditure in time series and panel data. Most of the studies are based on a simple relationship between health expenditure and economic growth. Important examples include Baltagi and Moscone [7], Amiri and Ventelou [8], Albouy, Laurent and Debrand [9], Bloom and Canning [10], Clemente, Marcuiello, Montanes and Pueyo [11], Bhargava, Jamison, Lau and Murray [12], Matteo and Matteo [13], Hansen and King [14], Murthy and Ukpolo [15], Leu [16]. Gyimah-Brempong and Wilson [17] find that the stock of health effect has positive and statistically significant effect on the growth of per capita income in both samples. They demonstrated that, this positive effect is quadratic: an increase in health human capital rises the growth of per capita income but the marginal effect eventually diminishes. Xiaoqing [18] investigates the effects of investment on physical capital and investment in health and economic growth in China. In this study he used, Cobb-Douglas Production Function which includes physical capital and health, as the research model. The article estimates a regressive model of economic growth and the results indicate the share of the GDP-investment ratio is increasing and also the article provides important insights about policy formulation and implementation. Baltagi and Moscone [7] explored the long-run economic relationship between health care expenditure and income in the OECD countries over the period 1971-2004. Their findings recommend that, health care is crucial rather than luxurious and it has much smaller elasticity than estimated in the previous studies. Bhargava, Jamison, Lau and Murray [12] examine the effects of health indicators such as the ratio of adult survival rates-GDP growth rates, at 5 year intervals in several countries. Panel data was analyzed on GDP series based on purchasing power adjustments and on exchange rates. In the study, analyzing instruments of eco- 
nometric estimators and test procedures were used in the analysis to draw inferences. Although the health of individuals in a country can only be, roughly, approximated in national averages, the models of paper showed significant effects of adult survival rates on economic growth rates for low income countries. The main aspect of their analysis was that, they estimated the threshold point beyond the typically negligible effects of adult survival rates on growth rates. Moscone and Tosetti [19] have focused on testing for error cross section independence in a panel where statistical units may be subjects to unobserved common effects, spatial spill overs, or both. Monte Carlo results display good small sample properties of such strategy. Erdil and Yetkiner [20] investigate the Granger-causality relationship between real per capita GDP and real per capita health care expenditure by employing a large macro panel data set with a VAR representation. The findings verify that the dominant type of Granger-causality is bidirectional. Gyimah-Brempong and Wilson [17] analyze the effects of health human capital on growth and use an expanded Solow growth model, panel data, and a dynamic panel estimator to investigate this relationship in samples of OECD and Sub Saharan African countries. They conclude that, the stock of health human capital has a positive and statistically significant effect on the growth of per capita income in both samples and this positive effect are quadratic. Narayan, Narayan and Mishra [21] investigate the relationship between health and economic growth. They conducted panel unit root, panel co-integration analyses with structural breaks and panel long-run estimator and they used investment, imports, exports and research/development as variables, for the period 1974-2007. Two main conclusions were reached: first they found that, in all four variants of the growth model, variables share a long-run relationship. The others have contributed positively to the economic growth and imports have a statistically significant negative effect on health expenditure while education has an insignificant effect on it.

\section{Data, Methodology and Models}

This study used a panel data set, which includes 15 OECD countries that had high income per capita, for the period 1995-2011 (Austria, Belgium, Denmark, Finland, France, Germany, Italy, Luxembourg, Netherlands, Norway, Portugal, Spain, Sweden, Switzerland and United Kingdom). There are two reasons for selecting these countries. Firstly these countries form a group of high-income countries. The other reason, according to the statistics of WHO [22], these countries have the highest rates of total health expenditure.

Description of the variables used, such as health expenditure, national income, population and age structure, is shown in Table 1. The data used in this paper is yearly and were obtained from WDI (World Development Indicator) and WHO (World Health Organization).

The economy policies show their effect on the applications of the macro and micro variables, in a delay of a specific time period. For example, the impact of an investment made today, in the health sector, shows its effect in future periods. Therefore in this study, ARDL method, which is a co-integration technique and introduced by Pesaran and Shin [22] and Pesaran, Shin and Smith [23], was used to analyze the lagged values. A long-run relationship in the economy has been the focus of the theoretical and empirical research. Pesaran and Smith [23] examine the use of autoregressive distributed lag (ARDL) models for the analysis of long-run relationships when the underlying variables are (I(1)).

The analysis becomes more complicated when the variables are difference-stationary, or integrated of order 1 $(I(1))$. The recent literature on co-integration is concerned with the analysis of the long-run relations between (I(1)) variables. Consequently, a large number of alternative estimations and hypotheses on testing procedures have been specifically developed for the analysis of $(I(1))$ variables [24]. According to the study of Paseran and Shin [24], the following basic ARDL $(p ; q)$ model will be considered as the main equation;

$$
\begin{gathered}
Y_{t}=\alpha_{0}+\alpha_{1} t+\sum_{i=1}^{p} \theta_{i} Y_{t-i}+\beta^{\prime} X_{t}+\sum_{i=0}^{q-1} \beta_{i}^{* \prime} \Delta X_{t-i}+u_{t} \\
\Delta X_{t}=P_{1} \Delta X_{t-1}+P_{2} \Delta X_{t-2}+\cdots+P_{i} \Delta X_{t-i}+\varepsilon_{t}
\end{gathered}
$$

where $X_{t}$ is the $k$-dimensional $(I(1))$ variables that are not cointegrated among themselves, $u_{t}$ and $\varepsilon_{t}$ are serially uncorrelated disturbances with zero means and constant variance-covariance, and $P_{i}$ are $k \times k$ coefficient matrices such that the vector autoregressive process in $\Delta X_{t}$ is stable.

It is needed to determine the order of integration before using co-integration techniques. For this aim; Levin, Lin \& Chi (LLC), Im, Pesaran and Shin (IPS), ADF Fisher Chi-square (ADF Fisher) AND PP-Fisher unit root tests are used in the paper. Panel unit root tests have been developed on the similar manner that underlie conven- 
tional ADF test. Table 1 shows the results of the panel unit root tests.

It is obvious from the ADF results that, some of the data sets are integrated of $(I(0))$ or $(I(1))$. The unit root test results of individual effect indicate that, LHE, LY, ADRO and LGE series are (I(1)), ADRY series are (I(0)) in Table 2. Therefore, we might apply ARDL bounds testing procedures for establishing the long-run relationship between health expenditure and income, old people, young people, government expenditure.

In our study, the model of Baltagi and Moscone [7] has been used. Co-integration could claim that there is a relationship between the associated variables. If the variables are co-integrated, then a vector error correction model (VECM) could be estimated with the error correction term. Panel VECM is obtained with following equations:

$$
\mathrm{LHE}_{i t}=\beta_{0 i}+\sum_{p=1}^{k} \beta_{1 i p} \mathrm{LY}_{i t-p}+\sum_{p=1}^{k} \beta_{2 i p} \mathrm{ADRO}_{i t-p}+\sum_{p=1}^{k} \beta_{3 i p} \mathrm{ADRY}_{i t-p}+\sum_{p=1}^{k} \beta_{2 i p} \mathrm{LGE}_{i t-p} \varphi_{1 i} \hat{\varepsilon}_{i t-1}+v_{1 i t}
$$

According to the causality results which are provided in the Table 3; while there is no causality to the variable $\triangle \mathrm{LHE}$ from $\triangle \mathrm{LY}$ in a short period of time, it could be mentioned about the presence of causality in long term. But there is causality from $\Delta \mathrm{LY}$ to $\triangle \mathrm{LHE}$. More clearly, there is bi-directional causality in long-run, between the health expenditure and income. These results support the results of the seminal works of Taban [25], Erdil and Yetkiner [20], Devlin and Hansen [26], Amiri and Ventelou [8]. In short-run there is a unidirectional causality from health expenditure to income in some other studies such as Chen, Clarke and Roy [27], Rahman [28].

In this study we employed PMG estimation introduced by Pesaran, Shin and Smith [28]. It is assumed that an autoregressive distributive lag (ARDL) can be represents equation 1 ; in equation $1 t$ trend $\sum_{i=1}^{p} \theta_{i} Y_{t-i}$ is a dependent variable (LHE), $\Delta X_{t-i}$ is $k \times 1$ vector of regressors (independent variable LY,ADRO, ADRY, LGE) for group.

MG estimation method proposed by Pesaran and Smith [23] is obtained from autoregressive distributed lag models for each unit consisting of (ARDL) long-term average by using the coefficients of the long-term.

Table 4 shows the results of Hausman Test conducted in order to test the hypothesis of the long-run elasticity. Hausman Test was also conducted to test the homogeneity in long-term. According to the results in Table 4, null hypothesis is not rejected and thus, Pooled Mean Group Estimation (PMG) is a valid estimator. PMG and MG estimators of this paper are made for the short (SR) and long term (LR).

MG estimator seems not to be valid but LY, ECT, LY $(-1)$, ADRY $(-2)$ veLGE co-efficients are statistically significant in SR and LR period. According to PMG in LR while all co-efficients are statistically significant, ADRO and ADRY only in the short term are meaningless. This study highlights several implications in LR. At first, respectively the largest and the smallest impact on health expenditures is caused by public spending $(\mathrm{LGE}=1.7269)$ and age dependency ratio young $(\mathrm{ADRO}=-0.0165)$. As another result, the influence of income and ADRO on health expenditures is positive $(\mathrm{LY}=0.7762$ and $\mathrm{ADRO}=0.4751)$. On the other hand, when the young working population $(\mathrm{ADRY}=-0.0165)$ rate increases, health expenditure is decreasing. This situation is adverse for the age dependency ratio old $(A D R O=0.4751)$. In other words, ADRO increases the health expenditures. The demographic change will have an explicit influence on health policies in the future.

\section{Conclusion}

This study used a panel data set, which includes 15 OECD countries which had high income per capita, for the

Table 1. Description of variables.

\begin{tabular}{cc}
\hline Variables & Description \\
\hline LHE & Logarithm of Health Expenditure per Capita \\
LY & Logarithm of GDP per Capita \\
ADRO & Age Dependency Ratio, Old (\% of Working Age Population) \\
ADRY & Age Dependency Ratio, Young (\% of Working Age Population) \\
LGE & Logarithm of General Government Final Consumption \\
\hline
\end{tabular}


Table 2. Panel Unit Root.

\begin{tabular}{|c|c|c|c|c|}
\hline & \multicolumn{4}{|c|}{ Individual Intercept } \\
\hline & LLC & IPS & ADF Fisher & PP-Fisher \\
\hline LHE & $-3.4015(0.0003)$ & $1.7600(0.9608)$ & $14.3959(0.9927)$ & $20.5466(0.9015)$ \\
\hline LY & $-6.7574(0.0000)$ & $-2.5400(0.0055)$ & $48.3752(0.0182)$ & $74.9286(0.0000)$ \\
\hline ADRO & $-0.8565(0.1959)$ & $0.6446(0.7404)$ & $81.0329(0.0000)$ & $20.6911(0.8973)$ \\
\hline ADRY & $-20.2487(0.0000)$ & $-27.2769(0.0000)$ & $232.590(0.0000)$ & $83.9225(0.0000)$ \\
\hline LGE & $-5.4892(0.0000)$ & $0.5595(0.7121)$ & $28.2008(0.5598)$ & $42.4360(0.0656)$ \\
\hline$\Delta \mathrm{LHE}$ & $-1.5224(0.0639)$ & $-2.2097(0.0136)$ & $45.3447(0.0358)$ & $83.0441(0.000)$ \\
\hline$\Delta \mathrm{LY}$ & $-6.2180(0.0000)$ & $-3.1361(0.0009)$ & $53.6936(0.0050)$ & $75.9320(0.0000)$ \\
\hline$\triangle \mathrm{ADRO}$ & $-4.8418(0.0000)$ & $-4.4227(0.0000)$ & $100.890(0.0000)$ & $8.0994(1.0000)$ \\
\hline$\triangle \mathrm{ADRY}$ & $-9.2499(0.0000)$ & $-4.3374(0.0000)$ & $87.8882(0.0000)$ & $68.4171(0.0000)$ \\
\hline \multirow[t]{2}{*}{$\Delta \mathrm{LGE}$} & $-1.4138(0.0787)$ & $-2.4874(0.0064)$ & $55.2328(0.0033)$ & $83.1283(0.0000)$ \\
\hline & \multicolumn{4}{|c|}{ Individual Intercept and Trend } \\
\hline LHE & 3.4618 (0.9997) & $1.98380(0.9764)$ & $18.9048(0.9420)$ & $9.5295(0.9999)$ \\
\hline LY & $-2.4113(0.0079)$ & $1.4735(0.9297)$ & $19.4546(0.9300)$ & $7.8585(1.0000)$ \\
\hline ADRO & $-7.6865(0.0000)$ & $-7.3390(0.0000)$ & $139.631(0.0000)$ & $7.2918(1.0000)$ \\
\hline ADRY & $-16.4703(0.0000)$ & $-7.3958(0.0000)$ & $116.251(0.0000)$ & $72.4029(0.0000)$ \\
\hline LGE & $2.0645(0.9805)$ & $2.3090(0.9895)$ & $20.3599(0.9068)$ & 11.7933 (0.9988) \\
\hline$\Delta \mathrm{LHE}$ & $-2.4042(0.0081)$ & $-0.4707(0.3189)$ & $32.8224(0.3303)$ & $66.9182(0.0001)$ \\
\hline$\Delta \mathrm{LY}$ & $-8.0592(0.0000)$ & $-3.9904(0.0000)$ & $64.9759(0.0002)$ & $113.367(0.0000)$ \\
\hline$\triangle \mathrm{ADRO}$ & $-12.7757(0.0000)$ & $-10.5698(0.0000)$ & $110.165(0.0000)$ & $3.3232(1.0000)$ \\
\hline$\triangle \mathrm{ADRY}$ & $-7.5380(0.0000)$ & $-7.4602(0.0000)$ & $78.3868(0.0000)$ & $48.6058(0.0172)$ \\
\hline$\Delta \mathrm{LGE}$ & $-2.9817(0.0014)$ & $-1.9436(0.0260)$ & $52.2095(0.0072)$ & $66.8027(0.0001)$ \\
\hline
\end{tabular}

Table 3. Panel granger causality.

\begin{tabular}{ccrc}
\hline & Short-Run Causality & Long-Run Causality & ECT \\
\hline LHE & $\Delta \mathrm{LY}$ & $\Delta \mathrm{LHE}$ & $5.36 \mathrm{E}-05(1.1 \mathrm{E}-05)$ \\
$\Delta \mathrm{LY}$ & $0.9417(0.6245)$ & $13.0111(0.0015)$ & $-0.26147(0.0291)$ \\
\hline
\end{tabular}

Table 4. Pool mean group and mean group estimations of ARDL.

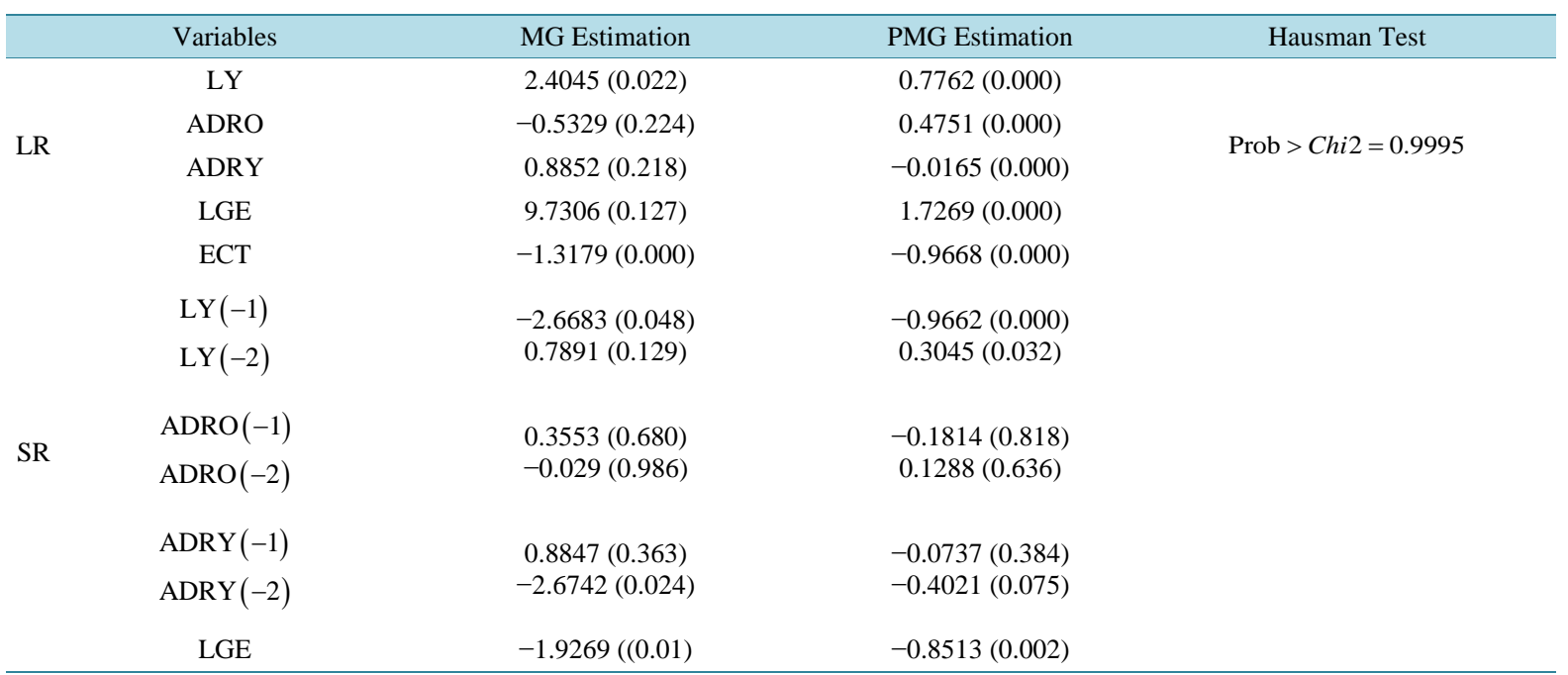


period of 1995-2011. Applications in the economy of macro and micro variables can be influenced by lagged values from policies. For example, the impact of an investment made today in the health sector exist in future periods. Therefore this paper was used to analyze lagged values of ARDL cointegration method that was proposed by Pesaran, Shin and Smith [29] and Pesaran and Shin [30].

This study highlights several implications in LR. At first, respectively the largest and the smallest impact on health expenditures is caused by public spending and age dependency ratio: young. Another result influence of income and ADRO on health expenditures is positive. Another striking inference is that when the young working population rate increases, health expenditure is decreasing. This situation is the opposite for age dependency ratio: old. In OECD countries, the share of young population ratio is low. Thus instead of increasing the share of health expenditures, demographic structure rejuvenation policy would be a better choice in the long run.

\section{References}

[1] Solow, R.M. (1956) A Contribution to the Theory of Economic Growth. The Quarterly Journal of Economics, 70, 6594.

[2] Easterly, W.R. and Wetzel, D.L. (1989) Policy Determinants of Growth: Survey of Theory and Evidence. PPR Working Paper Series, 343, The World Bank.

[3] Schultz, T.P. (1997) Assessing the Productive Benefits of Nutrition and Health: An Integrated Human Capital Approach. Journal of Econometrics, 77, 141-158. http://dx.doi.org/10.1016/S0304-4076(96)01810-6

[4] Lucas Jr., R.E. (1988) On the Mechanics of Economic Development. Journal of Monetary Economics, 22, 3-42. http://dx.doi.org/10.1016/0304-3932(88)90168-7

[5] Barro, R. (1999) Human Capital and Growth in Cross Country Regressions. Swedish Economic Policy Review, 6, 237277.

[6] Romer, P.M. (1986) Increasing Returns and Long-Run Growth. The Journal of Political Economy, 94, 1002-1037. http://dx.doi.org/10.1086/261420

[7] Baltagi, B.H. and Moscone, F. (2010) Health Care Expenditure and Income in the OECD Reconsidered: Evidence from Panel Data. Economic Modelling, 27, 804-811. http://dx.doi.org/10.1016/j.econmod.2009.12.001

[8] Amiri, A. and Ventelou, B. (2012) Granger Causality between Total Expenditure on Health and GDP in OECD: Evidence from the Toda-Yamamoto Approach. Economics Letters, 116, 541-544.

http://dx.doi.org/10.1016/j.econlet.2012.04.040

[9] Albouy, V., Laurent D. and Debrand, T. (2010) Health Expenditure Models: A comparison Using Panel Data. Economic Modelling, 27, 791-803. http://dx.doi.org/10.1016/j.econmod.2010.02.006

[10] Bloom, D.E. and Canning, D. (2005) Health and Economic Growth: Reconciling the Micro and Macro Evidence. Working Paper, Harvard University.

[11] Clemente, J., Marcuiello, C., Montañes, A. and Pueyo, F. (2004) On the International Stability of Health Care Expenditure Functions: Are Government and Private Functions Similar? Journal of Health Economics, 23, 589-613. http://dx.doi.org/10.1016/j.jhealeco.2003.08.007

[12] Bhargava, A., Jamison, D.T., Lau, L.J. and Murray, C.J.L. (2001) Modeling the Effects of Health on Economic Growth. Journal of Health Economics, 20, 423-440. http://dx.doi.org/10.1016/S0167-6296(01)00073-X

[13] Di Matteo, L. and Di Matteo, R. (1998) Evidence on the Determinants of Canadian Provincial Government Health Expenditures: 1965-1991. Journal of Health Economics, 17, 211-228. http://dx.doi.org/10.1016/S0167-6296(97)00020-9

[14] Hansen, P. and King, A. (1996) The Determinants of Health Care Expenditure: A Cointegration Approach. Journal of Health Economics, 15, 127-137. http://dx.doi.org/10.1016/0167-6296(95)00017-8

[15] Murthy, N.R.V. and Ukpolo, V. (1994) Aggregate Health Care Expenditure in the United States: Evidence from Cointegration Tests. Applied Economics, 26, 797-802. http://dx.doi.org/10.1080/00036849400000094

[16] Leu, R.E. (1986) Public and Private Health Services: Complementarities and Conflicts. In: Culyer, A.J. and Jönsson, B., Eds., Blackwell, Oxford, 41-63.

[17] Gyimah-Brempong, K. and Wilson, M. (2004) Health Human Capital and Economic Growth in Sub-Saharan African and OECD Countries. The Quarterly Review of Economics and Finance, 44, 296-320. http://dx.doi.org/10.1016/j.qref.2003.07.002

[18] Xie, X.Q. (2005) Investment in Physical Capital, Investment in Health and Economic Growth in China. Investment Management and Financial Innovation, 1, 23-29.

[19] Moscone, F. and Tosetti, E. (2010) Testing for Error Cross Section Independence with an Application to US Health 
Expenditure. Regional Science and Urban Economics, 40, 283-291. http://dx.doi.org/10.1016/j.regsciurbeco.2009.08.004

[20] Erdil, E. and Yetkiner, I.H. (2009) The Granger-Causality Between Health Care Expenditure and Output: A Panel Data Approach. Applied Economics, 41, 511-518. http://dx.doi.org/10.1080/00036840601019083

[21] Narayan, S., Narayan, P.K. and Mishra, S. (2010) Investigating the Relationship between Health and Economic Growth: Empirical Evidence from a Panel of 5 Asian Countries. Journal of Asian Economics, 21, 404-411. http://dx.doi.org/10.1016/j.asieco.2010.03.006

[22] World Health Statistics (2013) Who Library Cataloguing-in-Publication Data. http://www.who.int/gho/publications/world_health_statistics/EN_WHS2013_Full.pdf?ua=1

[23] Pesaran, M.H. and Smith, R. (1995) Estimating Lon-Run Relationship from Dynamic Heterogeneous Panels. Journal of Econometrics, 68, 79-113. http://dx.doi.org/10.1016/0304-4076(94)01644-F

[24] Pesaran, M.H. And Shin, Y. (1997) Long Run Structural Modelling. Unpublished Manuscript, University of Cambridge, Cambridge.

[25] Taban, S. (2006) Türkiye’de Sağlık ve Ekonomik Büyüme arasındaki Nedensellik İlişkisi. Sosyoekonomi, 2, Article ID: 060202.

[26] Devlin, N. and Hansen, P. (2001) Health Care Spending and Economic Output: Granger Causality. Applied Economics Letters, 8, 561-564. http://dx.doi.org/10.1080/13504850010017357

[27] Chen, W.C., Clarke, J.A. and Roy, N. (2013) Health and Wealth: Short Panel Granger Causality Tests for Developing Countries. The Journal of International Trade \& Economic Development: An International and Comparative Review, 23, 755-784.

[28] Rahman, Md.M. (2011) Causal Relationship among Education Expenditure, Health Expenditure and GDP: A Case Study for Bangladesh. International Journal of Economics and Finance, 3, 149-159. http://dx.doi.org/10.5539/ijef.v3n3p149

[29] Pesaran, M.H., Shin, Y. and Smith, R. (2001) Bounds Testing Approaches to the Analysis of Level Relationships. Journal of Applied Econometrics, 16, 289-326. http://dx.doi.org/10.1002/jae.616

[30] Pesaran, M.H. and Shin, Y. (1999) An Autoregressive Distributed Lag Modeling Approach to Cointegration Analysis. In: Strom, S., Ed., Econometrics and Economic Theory in the 20th Century, Chapter 11, The Ragnar Frisch Centennial Symposium, Cambridge University Press, Cambridge. 
Scientific Research Publishing (SCIRP) is one of the largest Open Access journal publishers. It is currently publishing more than 200 open access, online, peer-reviewed journals covering a wide range of academic disciplines. SCIRP serves the worldwide academic communities and contributes to the progress and application of science with its publication.

Other selected journals from SCIRP are listed as below. Submit your manuscript to us via either submit@scirp.org or Online Submission Portal.
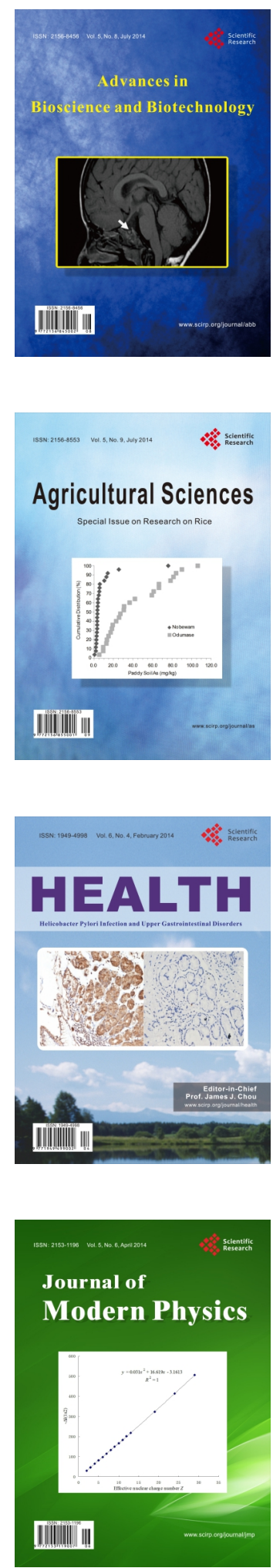
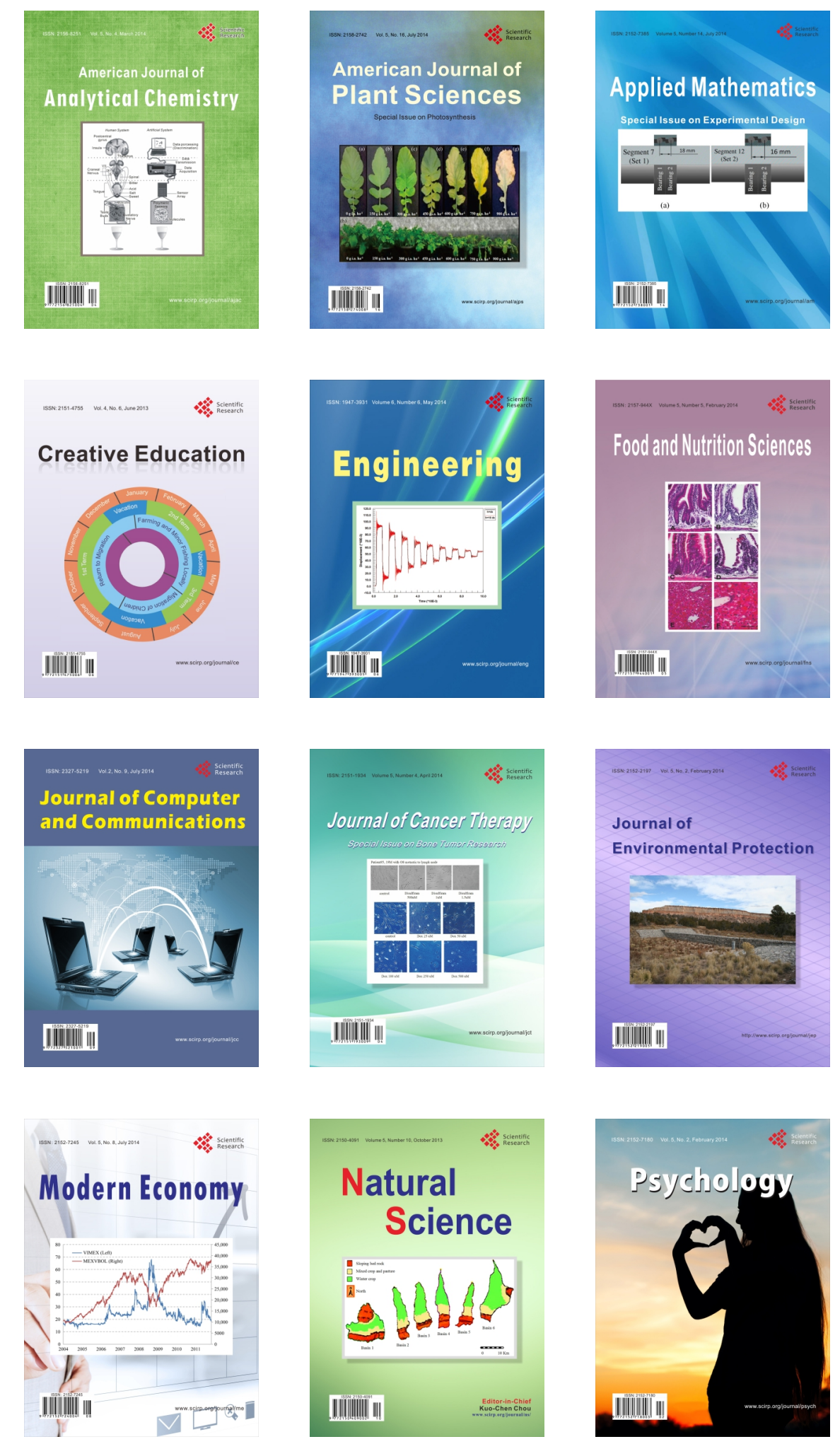